\title{
Preliminary Study on the Effect of Fermented Cheese Whey on Listeria monocytogenes, Escherichia coli O157:H7, and Salmonella Goldcoast Populations Inoculated onto Fresh Organic Lettuce
}

\author{
Maria I.S. Santos, ${ }^{1-4}$ Ana I. Lima, Sara A.V.S. Monteiro, Ricardo M.S.B. Ferreira, \\ Laurentina Pedroso, ${ }^{3}$ Isabel Sousa, and Maria A.S.S. Ferreira ${ }^{1}$
}

\begin{abstract}
Cheese whey fermented by an industrial starter consortium of lactic acid bacteria was evaluated for its antibacterial capacity to control a selection of pathogenic bacteria. For their relevance on outbreak reports related to vegetable consumption, this selection included Listeria monocytogenes, serotype 4b, Escherichia coli O157:H7, and Salmonella Goldcoast. Organically grown lettuce was inoculated with an inoculum level of $\sim 10^{7}$ colonyforming unit $(\mathrm{CFU}) / \mathrm{mL}$ and was left for about $1 \mathrm{~h}$ in a safety cabinet before washing with a perceptual solution of 75:25 (v/v) fermented whey in water, for 1 and $10 \mathrm{~min}$. Cells of pathogens recovered were then counted and their number compared with that obtained for a similar treatment, but using a chlorine solution at $110 \mathrm{ppm}$. Results show that both treatments, either with chlorine or fermented whey, were able to significantly reduce $(p<0.05)$ the number of bacteria, in a range of 1.15-2.00 and 1.59-2.34 CFU/g, respectively, regarding the bacteria tested. Results suggest that the use of fermented whey may be as effective as the solution of chlorine used in industrial processes in reducing the pathogens under study (best efficacy shown for Salmonella), with the advantage of avoiding health risks arising from the formation of carcinogenic toxic chlorine derivates.
\end{abstract}

\section{Introduction}

D UE TO INTEREST for healthier diets, the demand of fruits and vegetables, whole or minimally processed (MP), has been increasing over the last few years (OMAIAA, 2011; Olaimat and Holley, 2012). However, the number of outbreaks and cases of foodborne illnesses associated to the consumption of leafy vegetables has increased in the last few years, and consequently, the concern about the presence of pathogens in these foodstuffs (Sagong at al., 2011; Painter et al., 2013).

In fact, the contamination of vegetables reflects the microbiota of the environment where they are cultivated (Tauxe et al., 1997; Holden et al., 2009). In addition, mishandling of vegetables during harvest and postharvest, transportation, processing, and packaging can also turn these products into vehicles of pathogenic microorganisms (Heard, 2002). Data from the United States, in the period between 1998 and 2008, reported that fruits and vegetables accounted for $46 \%$ of the foodborne diseases (most often caused by norovirus, Salmonella spp., and Escherichia coli O157:H7), with leafy vegetables belonging to the largest numbers (Painter et al., 2013). Europe reported, from 2008 to 2013, 215 outbreaks of food and waterborne diseases, $63 \%$ related to salmonellosis, with $31 \%$ linked to vegetables. The great German outbreak with 50 deaths caused by E. coli O104:H4 is within the last category (WHO, 2011; Gossner et al., 2015). Salmonella spp., E. coli O157:H7, and Listeria monocytogenes are the pathogens of major concern implicated in numerous outbreaks of foodborne illnesses associated to the consumption of leafy vegetables, according to Sagong et al. (2011).

Washing with sanitizers is normally the only step used in MP leafy vegetables, to assure the reduction in the number of pathogens and spoilage microorganisms. Chlorine has been the sanitizer more often used in industry, to ensure the safety of this food product. Meanwhile, concern about the

\footnotetext{
${ }^{1}$ Microbiology Laboratory, Department of Natural Resources, Environment and Territory, DRAT, LEAF, Instituto Superior de Agronomia, Universidade de Lisboa, Lisbon, Portugal.

${ }^{2}$ Eco-Processing of Food and Feed, CEE, LEAF, Instituto Superior de Agronomia, Universidade de Lisboa, Lisbon, Portugal.

${ }^{3}$ Faculty of Veterinary Medicine, Universidade Lusofona de Humanidades e Tecnologias, Lisbon, Portugal.

${ }^{4}$ Disease \& Stress Biology, DRAT, LEAF, Instituto Superior de Agronomia, Universidade de Lisboa, Lisbon, Portugal.
} 
environmental and consumers' health risk due to the formation of chlorine carcinogenic toxic derivatives, like trihalomethanes and chloramines, has led to increased research on new methodologies that simultaneously reduce pathogens and toxic chemicals (Sapers, 2003; Martin-Diana et al., 2006; Martinez-Sanchez et al., 2006; Gil et al., 2009; Ölmez and Kretzschmar, 2009; Francis et al., 2012). Our previous work (Santos et al., 2015) used naturally fermented cheese whey, containing industrial lactic acid starter bacteria, as a sanitizer with promising results on hygiene indicator microorganism reduction. The present work was performed to evaluate if that antibacterial effect demonstrated for fermented cheese whey has the same magnitude of inhibition over the three major pathogens reported in outbreaks and linked to consumption of raw vegetables. This study was conducted to assess if the contact time of 1 and 10 min of fermented cheese whey and sodium hypochlorite solutions are equally efficient as sanitizers against these three pathogens spiked onto lettuce leaves.

\section{Materials and Methods}

\section{Bacterial strains and culture preparation}

Three bacterial species, found in higher frequency on raw fruits and vegetables and reported on outbreaks (SCF, 2002), were selected to be used in this work following the recommendations of the European Standard EN 1276:2009. L. monocytogenes NCTC 11994, serotype 4b, Salmonella Goldcoast NCTC 13175, and E. coli O157:H7 NCTC 12900 were provided by the Food Microbiology Laboratory, Instituto Nacional de Saúde Dr. Ricardo Jorge, Lisbon, Portugal. Inocula were prepared from stock cultures stored at $-80^{\circ} \mathrm{C}$, transferred into $10 \mathrm{~mL}$ of brain-heart Infusion (Oxoid $^{\mathrm{TM}}$, Hampshire, United Kingdom) for two consecutive cultures with $24 \mathrm{~h}$ intervals, struck afterward on Tryptone Soya Agar with Yeast Extract (TSYEA; bioMérieux ${ }^{\circledR}$ SA, Marcy l'Étoile, France), and incubated at $37^{\circ} \mathrm{C} \pm 1{ }^{\circ} \mathrm{C}$ overnight. A suspension of these cultures was made in Maximum Recovery Diluent (MRD; bioMérieux SA), corresponding to $\sim 10^{7}$ colony-forming unit $(\mathrm{CFU}) / \mathrm{mL}$. Bacterial populations in these suspensions were determined by surface plating duplicate samples on Compass ${ }^{\circledR}$ Listeria Agar, Compass Salmonella Agar, and CT-SMAC (all Biokar Diagnostics, Beauvais, France) for L. monocytogenes, Salmonella Goldcoast, and E. coli O157:H7, respectively. After serial dilution in $\mathrm{MRD}$, the plates were incubated at $37^{\circ} \mathrm{C} \pm 1^{\circ} \mathrm{C}$ for $24 \mathrm{~h}$, after which colony counts were recorded.

\section{Sample inoculation}

Lettuce (Lactuca sativa var. crispa), manure fertilized grade, was purchased from a certified organic grower, at a local market. Two or three damaged outer lettuce leaves were discarded in all samples and the unspoiled ones were cut, using a metal cutter with $6 \mathrm{~cm}$ diameter. Samples of leaves $(50 \mathrm{~g})$ were spiked by immersion in $500 \mathrm{~mL}$ of MRD containing individually the suspensions of bacteria described above, for $1 \mathrm{~min}$. Afterward, each inoculum was decanted and the lettuce placed separately on a sterile perforated tray to drain and left to dry in a biosafety cabinet at room temperature $\left(22^{\circ} \mathrm{C} \pm 4^{\circ} \mathrm{C}\right)$ for about $1 \mathrm{~h}$.

\section{Preparation of washing solutions}

Whey, obtained as waste from a cheese factory, fermented as previously described (Santos et al., 2015) has, undiluted, a batch average of $(\mathrm{g} / \mathrm{L})$ : lactic acid 18 , acetic acid 0.89 , ethanol 7.46, and a final $\mathrm{pH}$ of 3.19. A percentage solution of fermented whey in water $(75: 25, \mathrm{v} / \mathrm{v})$ and a chlorine solution (110 ppm) were prepared as previously used (Santos et al., 2015).

\section{Washing treatments}

Lettuce leaves $(10 \mathrm{~g})$, spiked with each one of the bacterial species, were placed into a Stomacher bag (PE; Seward Ltd., London, United Kingdom) either with: (1) no sanitizer solutions (control), (2) $50 \mathrm{~mL}$ of $110 \mathrm{ppm}$ sodium hypochlorite or (3) $50 \mathrm{~mL}$ of diluted fermented whey for 1 and $10 \mathrm{~min}$ of contact time. All samples were shaken at $4^{\circ} \mathrm{C}$ using an incubator with orbital shaking (Panasonic MIR 154, Tokyo, Japan).

We consider the initial bacterial load that was attached onto lettuce leaves, as determined for treatment of (1) our control reference, because previous studies revealed that washing with water reduced 0.5-1.0 log CFU/g (Singh et al., 2002; Sagong et al., 2011; Santos et al., 2015).

\section{Microbiological analyses}

After the washing step, leaves were transferred into new sterile Stomacher bags, diluted 1:10 with Buffered Peptone Water (bioMérieux SA) and then homogenized in the Stomacher (Stomacher 400 Circulator; Seward Limited, London, United Kingdom) for $1 \mathrm{~min}$ at $230 \mathrm{rpm}$ for bacterial evaluations. Serial dilutions of the initial suspensions were made in MRD and then surface plated in duplicate $(0.1 \mathrm{~mL})$ onto Compass Listeria Agar, Compass Salmonella Agar, and CT-SMAC, with incubation at $37^{\circ} \mathrm{C} \pm 1^{\circ} \mathrm{C}$ for $24 \pm 2 \mathrm{~h}$. To assure that only the spiked bacteria were recovered and compared with the initial load, representative colonies were picked up to TSYEA for confirmation and, subsequently, inoculated into API Listeria (bioMérieux SA), Triple Sugar Iron, and Indole test (both Biogerm, Maia, Portugal), for L. monocytogenes, Salmonella Goldcoast, and E. coli O157:H7, respectively, for biochemical identification.

\section{Statistical analysis}

Counts were statistically analyzed using the software SigmaPlot (version 12.5) from StatSoft (Tulsa, OK), to perform a two-way analysis of variance with a Tukey's test to compare differences between groups at $p<0.05$.

\section{Results and Discussion}

Fresh organic lettuce leaves inoculated with L. monocytogenes, serotype 4b, E. coli O157:H7, and Salmonella Goldcoast were used to assess the effect of fermented cheese whey on the reduction of bacterial cell numbers. Immediately after inoculation, lettuce samples used as control, presented initial populations of L. monocytogenes, E. coli O157:H7, and Salmonella Goldcoast of 6.34, 5.61, and 5.99 $\log \mathrm{CFU} / \mathrm{g}$, respectively. The reductions obtained after 1 and $10 \mathrm{~min}$ contact time with the sanitizer solutions assayed are presented in Table 1. As a general note, results show that both 
Table 1. Populations of Listeria MONOCYTOGENES, EsCheriChIA COLI O157:H7, and SALMONELLA Goldcoast Recovered from Lettuce Leaves Following Treatments

\begin{tabular}{|c|c|c|c|c|c|c|c|}
\hline \multirow{2}{*}{\multicolumn{2}{|c|}{ Assays }} & \multicolumn{6}{|c|}{ Strains } \\
\hline & & \multicolumn{2}{|c|}{ L. monocytogenes } & \multicolumn{2}{|c|}{ E. coli $O 157: H 7$} & \multicolumn{2}{|c|}{ Salmonella Goldcoast } \\
\hline $\begin{array}{l}\text { Contact } \\
\text { time ( } \text { min) }\end{array}$ & Treatments & $\begin{array}{l}\text { Population } \\
\text { recovered } \\
(\log C F U / g)\end{array}$ & $\begin{array}{c}\text { Reduction } \\
\left(\log C F U / g^{1}\right)\end{array}$ & $\begin{array}{l}\text { Population } \\
\text { recovered } \\
(\log C F U / g)\end{array}$ & $\begin{array}{c}\text { Reduction } \\
\text { (log } \\
\text { CFU/g) }\end{array}$ & $\begin{array}{l}\text { Population } \\
\text { recovered } \\
(\text { log } C F U / g)\end{array}$ & $\begin{array}{c}\text { Reduction } \\
(\text { log } \\
\text { CFU/g) }\end{array}$ \\
\hline \multirow[t]{3}{*}{1} & No sanitizer-initial cell load & $6.34 \pm 0.20^{\mathrm{a}}$ & - & $5.61 \pm 0.09^{\mathrm{a}}$ & - & $5.99 \pm 0.06^{\mathrm{a}}$ & - \\
\hline & Chlorine solution $(100 \mathrm{ppm})$ & $4.22 \pm 0.10^{\mathrm{b}}$ & $1.59 \pm 0.14$ & $2.68 \pm 0.10^{\mathrm{b}}$ & $2.20 \pm 0.02$ & $3.34 \pm 0.07^{\mathrm{b}}$ & $1.99 \pm 0.13$ \\
\hline & Fermented whey $(75: 25 \mathrm{v} / \mathrm{v})$ & $4.80 \pm 0.09^{\mathrm{c}}$ & $1.15 \pm 0.20$ & $2.97 \pm 0.06^{\mathrm{b}}$ & $1.98 \pm 0.04$ & $4.11 \pm 0.14^{\mathrm{d}}$ & $1.41 \pm 0.11$ \\
\hline \multirow{3}{*}{10} & No sanitizer-initial cell load & $6.34 \pm 0.20^{\mathrm{a}}$ & - & $5.61 \pm 0.09^{\mathrm{a}}$ & - & $5.99 \pm 0.06^{\mathrm{a}}$ & - \\
\hline & Chlorine solution (100 ppm) & $3.91 \pm 0.33^{\mathrm{b}}$ & $1.77 \pm 0.16$ & $2.80 \pm 0.72^{\mathrm{b}}$ & $2.12 \pm 0.64$ & $2.86 \pm 0.14^{\mathrm{c}}$ & $2.34 \pm 0.19$ \\
\hline & Fermented whey $(75: 25 \mathrm{v} / \mathrm{v})$ & $4.62 \pm 0.36^{\mathrm{c}}$ & $1.23 \pm 0.44$ & $3.11 \pm 0.57^{\mathrm{b}}$ & $1.89 \pm 0.49$ & $3.32 \pm 0.24^{\mathrm{e}}$ & $2.00 \pm 0.25$ \\
\hline
\end{tabular}

Values are mean \pm standard deviation of duplicates of three independent trials. Different letters represent significant differences between values $(p<0.05)$.

$\mathrm{CFU}$, colony-forming unit.

chlorine and fermented whey treatments were able to significantly reduce $(p<0.05)$ the level of all bacteria tested, compared to the numbers of bacterial cells present in the controls. However, the efficacy of the chlorine and whey treatments varied with the characteristics of the bacterial species under test.

With respect to the contact times studied, 1 and $10 \mathrm{~min}$ with chlorine or whey as sanitizers, the results show that no significant reduction $(p<0.05)$ was observed on numbers of $L$. monocytogenes by increasing the length of time. Grampositive bacterial cells are more permeable to molecules in general, due to their content in peptidoglycan and lipopolysaccharide of membranes.

However, for each contact time, significant differences were found in L. monocytogenes cell numbers between both sanitizers and the control, with chlorine producing slightly better results. Chlorine is forbidden as sanitizer of MP vegetables, in Germany, The Netherlands, Switzerland, and Belgium, for consumer health risk, due to formation of toxic compounds (Rico et al., 2007).

The results obtained for reduction in numbers of $\log \mathrm{CFU} / \mathrm{g}$ of Salmonella Goldcoast were essentially identical on the capacity of chlorine and fermented whey to remove Salmonella Goldcoast and L. monocytogenes cells from lettuce leaves. A significant difference in number reductions between both treatments, compared to the initial cell load used $(p<0.05)$, showed that chlorine was able to induce a higher reduction in bacterial counts and that the time of contact of both sanitizers is relevant.

Despite the fact that E. coli and Salmonella are both Gram-negative pathogens and belong to the same Enterobacteriaceae family, the effect of the sanitizers tested and the two times assayed as treatments produced different results.

Overall, it is possible to conclude that the duration of treatments ( 1 or $10 \mathrm{~min}$ ) did not produce a dramatic difference in cell count numbers for the three bacterial species under analysis. Nevertheless, small differences were encountered, with longer contact times of the inoculated lettuce leaves with the sanitizers (i.e., $10 \mathrm{~min}$ ) being more efficient in reducing bacterial cell numbers in the cases of L. monocytogenes and Salmonella Goldcoast and smaller (i.e., $1 \mathrm{~min}$ ) contact times originating better results in the case of E. coli $\mathrm{O} 157: \mathrm{H} 7$.

In a treatment with lactic acid at $2 \%(\mathrm{w} / \mathrm{v}$; a concentration higher than that used in the present study; the whey used in our experiments contained 1.4\% w/v lactic acid), Sagong et al. (2011) found a reduction of $1.74 \pm 0.38,1.73 \pm 0.16$, and $1.30 \pm 0.11$ for E. coli O157:H7, Salmonella Typhimurium, and $L$. monocytogenes, respectively, very similar to the reductions in numbers of $\log \mathrm{CFU} / \mathrm{g}$ we found in this work for equivalent bacterial species.

Many works have been published with alternative methods for vegetable disinfection, such as deionizer water (Beuchat, 1998; Singh et al., 2002; Rodgers et al., 2004; Ölmez and Akbas, 2009), hydrogen peroxide (Lin et al., 2000; Samadi et al., 2009), organic acids (Beuchat et al., 2004; Bari, et al., 2005; Martinez-Sanchez et al., 2006; Zhang et al., 2009), and irradiation (Minter and Foley, 2006; Sagong et al., 2011). As far as we are aware, solutions of whey fermented by lactic acid bacteria (LAB) have never been assayed before. LAB have been used traditionally for food preservation in dairy and meat products, as well as in fermented vegetables. The antimicrobial activity exhibited by LAB fermented whey may be explained by a set of characteristics, such as production of organic acids, mainly lactic acid, bioactive peptides, and hydrogen peroxide (Trias et al., 2008).

In conclusion, we can say that fermented cheese whey solution has achieved a significant reduction of the lettuce leaf-inoculated population of the three pathogenic bacteria studied, with results that closely approximate those obtained with the chemical sanitizer chlorine. Fermented whey is, therefore, a promising natural product that can be a good alternative to the use of chlorine in fresh vegetable disinfection. On a previous work, no color or change on general aspect of leaves was recorded (Santos et al., 2015). Because no extra washing is needed after treatments, one may add that fermented whey contains about $10^{6} \mathrm{CFU} / \mathrm{g}$ live natural LAB (Santos et al., 2015), known to have a beneficial modulating effect on the gut microbiota and to favor human health (Prakash et al., 2011).

This was a preliminary study with important outcomes, which open novel cost-effective and health-promoting perspectives in the disinfection of MP salads, using fermented 
whey, but being a preliminary result, further work should be done to test additional strains of each bacteria used, as well as other pathogenic bacteria and different exposure times.

\section{Acknowledgments}

The authors acknowledge the following institutions: Food Microbiology Laboratory of Instituto Nacional de Saúde Dr. Ricardo Jorge, Lisbon, Portugal, for providing the strains used in this work; and Sara Bernardes Silva, Technical Director of Indústria de Laticínios SA, Portugal, for kindly providing the whey used in this work.

\section{Disclosure Statement}

No competing financial interests exist.

\section{References}

Bari ML, Ukuku DO, Kawasaki R, Inatsu Y, Isshiki K, Kawamoto $\mathrm{S}$. Combined efficacy of nisin and pediocin with sodium lactate, citric acid, phytic acid, and potassium sorbate and EDTA in reducing the Listeria monocytogenes population of inoculated fresh-cut produce. J Food Prot 2005;68: 1381-1387.

Beuchat LR. Surface decontamination of fruits and vegetables eaten raw. Food Safety Issues, WHO/FSF/FOS/98.2, Food Safety Unit, World Health Organization, Geneva. 1998. Available at: http://apps.who.int/iris/bitstream/10665/64435/ 1/WHO_FSF_FOS_98.2.pdf?ua=1, accessed February 22, 2015.

Beuchat LR, Adler BB, Lang MM. Efficacy of chlorine and a peroxyacetic acid sanitizer in killing Listeria monocytogenes on iceberg and Romaine lettuce using simulated commercial processing conditions. J Food Prot 2004;67:1238-1242.

European Committee for Standardization. European Standard EN 1276:2009. Chemical disinfectants and antiseptics. Quantitative suspension test for the evaluation of bactericidal activity of chemical disinfectants and antiseptics used in food, industrial, domestic and institutional areas. Test method and requirements (phase 2 step 1 ).

Francis GA, Gallone A, Nychas GJ, Sofos JN, Colelli G, Amodio ML, Spano G. Factors affecting quality and safety of fresh-cut produce. Crit Rev Food Sci Nutr 2012;52:595-610.

Gil MI, Selma MV, López-Gálvez F, Allende A. Fresh-cut product sanitation and wash water disinfection: Problems and solutions. Int J Food Microbiol 2009;134:37-45.

Gossner CM, de Jong B, Hoebe CJ, Coulombier D. Event-based surveillance of food- and waterborne diseases in Europe: Urgent inquiries (outbreak alerts) during 2008 to 2013. Euro Surveill 2015;20:1-7.

Heard, GM. Microbiology of fresh-cut produce. In: Fresh-Cut Fruits and Vegetables: Science, Technology, and Market. Lamikanra O (ed.). Boca Raton: CRC Press, 2002, pp. 187248.

Holden N, Pritchard L, Toth I. Colonization outwith the colon: Plants as an alternative environmental reservoir for human pathogenic enterobacteria. FEMS Microbiol Rev 2009;33: 689-703.

Lin C, Moon SS, Doyle MP, Mathews KH. Inactivation of Escherichia coli O157:H7, Salmonella enteric serotype Enteritidis, and Listeria monocytogenes on lettuce by hydrogen peroxide and lactic acid and by hydrogen peroxide with mild heat. J Food Prot 2000;65:1215-1220.
Martin-Diana A, Rico D, Frias J, Mulcahy J. Whey permeate as a bio-preservative for shelf life maintenance. Innovative Food Sci Emerging Technol 2006;7:112-123.

Martinez-Sanchez A, Allende A, Bennett RN, Ferreres F, Gil MI. Microbial, nutritional and sensory quality of rocket leaves as affected by different sanitizers. Postharvest Biol Technol 2006;42:86-97.

Minter AM, Foley DM. Electron beam and gamma irradiation effectively reduce Listeria monocytogenes populations on chopped romaine lettuce. J Food Prot 2006;69:570-574.

Olaimat AN, Holley RA. Factors influencing the microbial safety of fresh produce: A review. Food Microbiol 2012;32: $1-19$.

Ölmez H, Akbas MY. Optimization of ozone treatment of freshcut green leaf lettuce. J Food Eng 2009;90:487-494.

Ölmez H, Kretzschmar U. Potential alternative disinfection methods for organic fresh-cut industry for minimizing water consumption and environmental impact. LWT Food Sci Technol 2009;42:686-693.

[OMAIAA] Observatório dos Mercados Agrícolas e Importações Agro-Alimentares. O mercado da alface em Portugal. Available at: www.observatorioagricola.pt/item.asp?id_ item=133, accessed February 22, 2015.

Painter JA, Hoekstra RM, Ayers T, Tauxe RV, Braden CR, Angulo FJ, Griffin PM. Attribution of foodborne illnesses, hospitalizations, and deaths to food commodities by using outbreak data, United States, 1998-2008. Emerg Infect Dis 2013;19:407-415.

Prakash S, Rodes L, Coussa-Charley M, Tomaro-Duchesneau C. Gut microbiota: Next frontier in understanding human health and development of biotherapeutics. Biologics 2011;5: 71-86.

Rico D, Martín-Diana A, Barat J, Barry-Ryan C. Extending and measuring the quality of fresh-cut fruit and vegetables: A review. Trends Food Sci Technol 2007;18:373-386.

Rodgers ST, Cash JN, Siddiq M, Ryser ET. A comparation of different chemical sanitizers for inactivating Escherichia coli O157:H7 and Listeria monocytogenes in solution and on apples, lettuce, strawberries, and cantaloupe. J Food Prot 2004;67:721-731.

Sagong H, Lee S, Chang P, Heu S, Ryu S, Choi Y, Dong-Hyun $\mathrm{K}$. Combined effect of ultrasound and organic acids to reduce Escherichia coli 0157:H7, Salmonella Typhimurium, and Listeria monocytogenes on organic fresh lettuce. Int J Food Microbiol 2011;145:287-292.

Samadi N, Abadian N, Bakhtiari D, Fazeli MR, Jamalifar H. Efficacy of detergents and fresh produce disinfectants against microorganisms associated with mixed raw vegetables. J Food Prot 2009;72:1486-1490.

Santos MIS, Martins, SR, Pedroso L, Sousa I, Ferreira MASS. Potential bio-activity of whey fermented extract as sanitizer of organic grown lettuce. Food Control 2015;50:477-481.

Sapers GM. Washing and sanitizing raw materials for minimally processed fruits and vegetables. In: Microbial Safety of Minimally Processed Foods. Novak JS, Sapers GM, and Juneja VK (eds.). Boca Raton: CRC Press, 2003, pp. 221-253.

SCF. Risk Profile on the Microbiology Contamination of Fruits and Vegetables Eaten Raw. Report of the Scientific Commission on Food, European Commission on Health and Consumer Protection Directorate-General, 2002.

Singh N, Singh RK, Bhunia AK, Stroshine RL. Effect of inoculation and washing methods on the efficacy of different sanitizers against Escherichia coli $\mathrm{O} 157: \mathrm{H} 7$ on lettuce. Food Microbiol 2002;19:183-193. 
Tauxe R, Kruse H, Hedberg C, Potter M, Madden J, Wachsmuth $\mathrm{K}$. Microbiological hazards and emerging issues associated with produce: A preliminary report to the National Advisory Committee on Microbiological Criteria for Foods. J Food Prot 1997;60:1400-1408.

Trias R, Bañeras L, Badosa E, Montesinos E. Bioprotection of golden delicious apples and Iceberg lettuce against foodborne bacterial pathogens by lactic acid bacteria. Int J Food Microbiol 2008;123:50-60.

WHO. Outbreaks of E. coli O104:H4 Infection: Update 30. Available at: www.euro.who.int/en/health-topics/disease-prevention/ food-safety/news/news/2011/07/outbreaks-of-e.-coli-o104h4infection-update-30, accessed June 26, 2015.

Zhang G, Ma L, Phelan VH, Doyle MP. Efficacy of antimicrobial agents in lettuce leaf processing water for control of Escherichia coli O157:H7. J Food Prot 2009;72:1392_ 1397.

Address correspondence to:

Maria A.S.S. Ferreira, PhD

Microbiology Laboratory

Department of Natural Resources,

Environment and Territory

DRAT, LEAF

Instituto Superior de Agronomia

Universidade de Lisboa

Lisbon 1349-017

Portugal

E-mail: massferreira@isa.ulisboa.pt 